\title{
STUDI TENTANG PENGARUH NITROCARBURIZING DC-PLASMA TERHADAP PERUBAHAN KEKERASAN DAN STRUKTUR MIKRO PADA MATERIAL Zr-4
}

\author{
USMAN SUDJADI \\ Pusat Teknologi Bahan Bakar Nuklir-BATAN
}

\begin{abstract}
Abstrak
STUDI TENTANG PENGARUH NITROCARBURIZING DC-PLASMA TERHADAP PERUBAHAN KEKERASAN DAN STRUKTUR MIKRO PADA MATERIAL Zr-4. Pengaruh nitrocarburizing terhadap perubahan kekerasan dan struktur mikro pada bahan $\mathrm{Zr}-4$ (bahan untuk cladding bahan bakar nuklir PWR) dengan alat nitrocarburizing DC plasma telah dipelajari. Beberapa samples telah di nitrocarburizing pada suhu $(550-700)^{\circ} \mathrm{C}$ selama 1 jam. Hasilnya menunjukkan bahwa, pada sample awal kekerasan $\mathrm{Zr}-4$ adalah 183,8 $\mathrm{HV}$, setelah di nitrocarburizing pada suhu $700^{\circ} \mathrm{C}$ selama 1 jam, kekerasannya menurun menjadi $153,1 \mathrm{HV}$, sedangkan kedalaman atom-atom nitrogen dan carbon yang terdifusi kedalam bahan $\mathrm{Zr}-4$ ialah 26 micrometer. Pengamatan mikrostruktur menunjukkan bahwa pada sample yang telah di nitrocarburizing pada $\mathrm{T}=700^{\circ} \mathrm{C}(\mathrm{t}=1 \mathrm{jam})$ terlihat jelas adanya lapisan atom-atom $\mathrm{N}$ dan $\mathrm{C}$ di dalam bahan $\mathrm{Zr}$-4. Hasil uji komposisi kimia menunjukkan bahwa pada sampel awal bahan $\mathrm{Zr}$-4 terdapat atom-atom $\mathrm{Zr}$, $\mathrm{O}, \mathrm{C}$, dan $\mathrm{P}$.
\end{abstract}

Kata kunci : nitrocarburizing, DC plasma, Zr-4, kekerasan, struktur mikro

\begin{abstract}
STUDY OF INFLUENCE OF NITROCARBURIZING TO HARDNESS AND MICROSTRUCTURE CHANGE ON $\mathrm{Zr}-4$ MATERIAL. Influence of nitrocarburizing to hardness and microstructure change on $\mathrm{Zr}-4$ material (material for cladding nuclerar fuel element PWR) with nitrocarburizing DC-plasma apparatus were studied. Some samples were nitrocarburized at temperature (550-700) 0C for 1 hour. The results shows that the hardness untreated sample of $\mathrm{Zr}-4$ material was $183.8 \mathrm{HV}$, after the sample nitrocarburized at temperature $700 \mathrm{OC}$ for 1 hour, the hardness decreasing to be $153.1 \mathrm{HV}$, furthermore depth of carbon and nitrogen atoms that difused in $\mathrm{Zr}-4$ material was 26 micrometer. Microstructure observation shows that the sample after nitrocarborized at temperature $7000 \mathrm{C}$ for 1 hour to be seen very clear that there are layer of $\mathrm{N}$ and $\mathrm{C}$ atoms in $\mathrm{Zr}-4$ material. The results of chemical composition shows that untreated sample consist of $\mathrm{Zr}, \mathrm{O}, \mathrm{C}$, and $\mathrm{P}$.
\end{abstract}

Keywords : nitrocarburizing, DC plasma, Zr-4, hardness, microstructure 


\section{PENDAHULUAN}

Teknologi pengerasan permukaan (surface hardening) pada bahan telah dilakukan beberapa peneliti dengan mempergunakan beberapa technologies ${ }^{[1-}$ 7]. Technologies tersebut melingkupi plasma nitriding dan nitrocarburizing, plasma immersion implantation, ECR ion nitriding, rf plasma nitriding dan nitrocarburizing, low pressure plasma assisted nitriding dan high current density ion beam nitriding ${ }^{[8]}$. Di Indonesia telah dibuat beberapa alat plasma nitriding seperti DC plasma nitriding di PTAPB-BATAN Yogyakarta dan alat nitrocarburizing di Fakultas Teknik metalurgi Universitas Indonesia. RF-plasma nitriding di Indonesia belum ada. Saat ini research group kami telah mengembangkan RF-plasma nitriding. Alatnya telah selesai dibuat dan berfungsi dengan baik, hasil penelitian akan dipublikasikan kemudian ${ }^{[9]}$.

Zirconium (zircaloy) yang paling utama digunakan dalam industri nuklir. Dalam reaktor nuklir, zircaloy diperlukan sebagai pelindung bahan bakar dari pendingin, pengungkung hasil fisi, pemindah panas, dan bahan struktur. Dengan demikian maka zircaloy harus mempunyai sifat mekanik yang baik, tahan korosi, dan serapan neutron rendah. Sebagai contoh zircaloy-2 untuk reactor air didih (BWR) dan zircaloy-4 digunakan untuk reactor air bertekanan (PWR) dengan suhu kelongsong $349^{\circ} \mathrm{C}$ untuk $\mathrm{BWR}^{[10]}$. Selain itu zircaloy dapat digunakan juga pada nozzle rocket karena bahan zircaloy tahan panas.

Meskipun bahan bakar nuklir yang memakai bahan Zr-4 sebagai cladding tidak banyak mengalami gesekan ataupun impack di dalam reaktor, namun tidak ada salahnya jika dipelajari pengaruh kekerasan dan struktur mikro dari proses nitrocarburizing pada bahan $\mathrm{Zr}-4$ sebagai basic research. Tidak semua bahan jika di nitrocarburizing akan bertambah kekerasannya. Dalam studi ini akan di pelajari perubahan kekerasan dan struktur mikro dari proses nitrocarburizing pada bahan zircaloy-4 (Zr-4). 


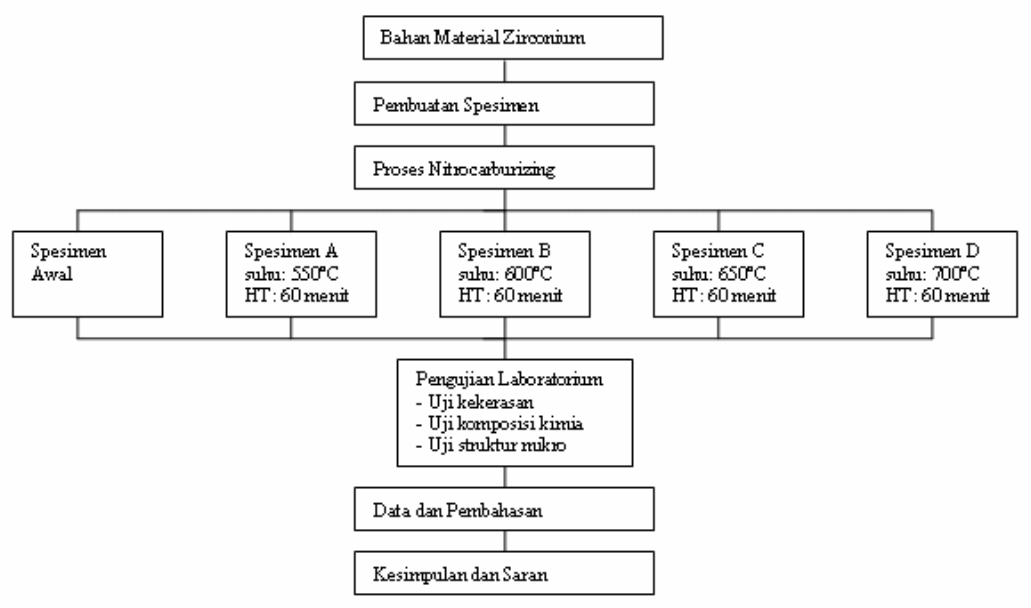

Gambar 1. Diagram Alir Penelitian

\section{Persiapan Sampel Penelitian}

Material yang akan di teliti dipotong-potong menjadi 5 buah, penandaan diberikan pada tiap sampel sesuai dengan suhu proses nitrocarburizing. Penandaan terdiri dari awal, A, B, C dan D yang menyatakan temperatur proses nitrocarburizing pada $550^{\circ} \mathrm{C}, 600^{\circ} \mathrm{C}, 650^{\circ} \mathrm{C}$ dan $700^{\circ} \mathrm{C}$. Untuk lebih jelasnya perhatikan Tabel 1 .

Tabel 1. Sampel yang Digunakan

\begin{tabular}{cccc}
\hline $\begin{array}{c}\text { Tanda } \\
\text { Sampel }\end{array}$ & $\begin{array}{c}\text { Jumlah } \\
\text { Sampel }\end{array}$ & $\begin{array}{c}\text { Suhu Proses } \\
\text { Nitrocarburizing } \\
\left({ }^{\circ} \mathrm{C}\right)\end{array}$ & $\begin{array}{c}\text { Holding Time } \\
\text { (menit) }\end{array}$ \\
\hline Awal & 1 & - & - \\
A & 1 & 550 & 60 \\
B & 1 & 600 & 60 \\
C & 1 & 650 & 60 \\
D & 1 & 700 & 60 \\
\hline
\end{tabular}

\section{Preparasi Permukaan}

Dalam melakukan proses nitrocarburizing sampel terlebih dahulu dibersihkan dan diratakan seluruh permukaannya agar kotoran-kotoran tidak melekat, terutama dari pelumas-pelumas atau oli, karena apabila sampel tidak bebas dari pelumas- pelumas atau oli akan terjadi letupan atau ledakan pada saat dimasukkan ke dalam dapur nitrocarburizing. 


\section{Proses Nitrocarburizing}

Sampel dimasukan ke dalam dapur fluidezed bed dengan program pada controllernya untuk proses nitrocarburizing pada suhu $550^{\circ} \mathrm{C}, 600^{\circ} \mathrm{C}, 650^{\circ} \mathrm{C}$ dan $700^{\circ} \mathrm{C}$ dengan lama waktu tahan sampai 60 menit.

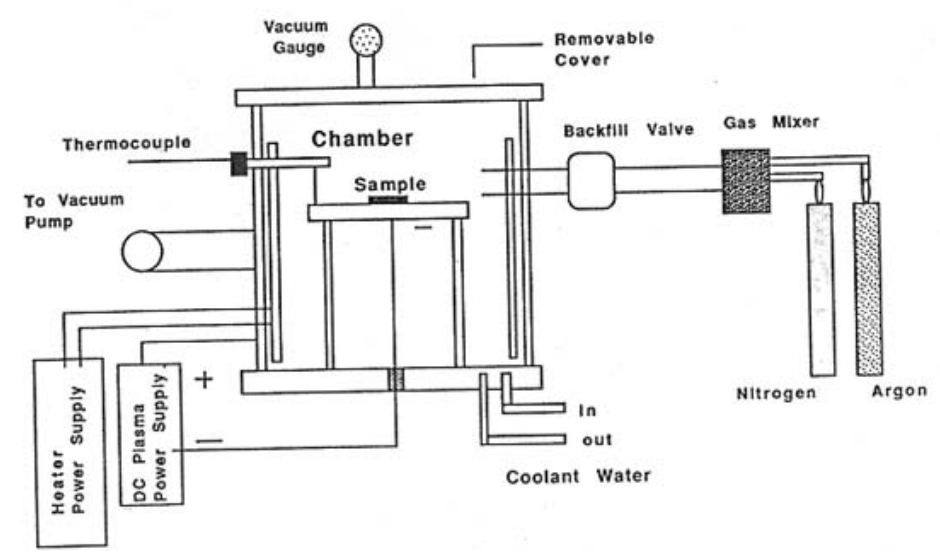

Gambar 2. Siklus Proses Nitrocarburizing

Setelah dilakukan proses nitrocarburizing, maka pada sampel dilakukan pendinginan kembali dengan cara didiamkan dengan suhu ruang (quenching). Setelah di quenching sampel diuji kekerasan dengan alat O.M.A.G MIKROHARDNESS HV.MHX.10 dengan waktu penjejakan 15 detik, beban penjejakan 300 gram. Kemudian sampel diamati struktur mikro serta ketebalan lapisan atom-atom carbon dan nitrogen yang telah terdifusi ke dalam bahan $\mathrm{Zr}-4$ dengan alat optical microscope dengan perbesaran $100 \mathrm{x}$ dan 500x, namun sebelumnya sampel mengalami proses preparasi yaitu grinding, polishing, mounting dan etching. Pengujian komposisi kimia menggunakan alat Spektrometer merk LEO 420i.

\section{HASIL DAN PEMBAHASAN}

\section{Hasil Uji Kekerasan}

Di bawah ini merupakan perhitungan dan tabel data hasil dari uji kekerasan, uji kekerasan yang digunakan adalah uji kekerasan vickers (HV). Hasil dari uji kekerasan di bawah ini adalah hasil uji dari sampel awal dan sampelsampel setelah mengalami proses nitrocarburizing pada suhu $550^{\circ} \mathrm{C}, 600^{\circ} \mathrm{C}$, $650^{\circ} \mathrm{C}, 700^{\circ} \mathrm{C}$ dengan waktu penahanan yang sama yaitu 60 menit, dengan beban penjejakan 300 gram dan waktu penjejakan 15 detik. Perhitungan hasil kekerasan sampel awal. 
Tabel 2. Diagonal Penjejakan

\begin{tabular}{cccccc}
\hline Spesimen & Titik 1 & Titik 2 & Titik 3 & Titik 4 & Titik 5 \\
& $d_{1}(\mathrm{~mm})$ & $d_{2}(\mathrm{~mm})$ & $d_{3}(\mathrm{~mm})$ & $\begin{array}{c}d_{4}(\mathrm{~mm}) \\
d_{5}(\mathrm{~mm})\end{array}$ \\
\hline Awal & 55 & 55 & 55 & 55 & 55 \\
$550 \mathrm{~A}$ & 55,5 & 56 & 56 & 56 & 56,5 \\
$600 \mathrm{~B}$ & 56 & 56,5 & 56,5 & 57 & 57 \\
$650 \mathrm{C}$ & 57,5 & 58 & 58,5 & 58,5 & 68,5 \\
$700 \mathrm{D}$ & 59 & 59,5 & 60,5 & 61 & 61,5 \\
\hline
\end{tabular}

Dari data di atas dapat diketahui berapa nilai kekerasan yang ada pada spesimen. Dengan contoh perhitungan sebagai berikut : $\mathrm{P}=300$ gram, $\mathrm{j}=100$ micron, spesimen awal :

$$
H V_{1}=\frac{1,854 \times P \times 1000}{\left(d_{1}\right)^{2}} \equiv \frac{1,854 \times 300 \times 1000}{(55)^{2}} \equiv \frac{556,200}{3.025} \equiv 183,8 \mathrm{~kg} / \mathrm{mm}^{2}
$$

Dari hasil perhitungan diatas dapat diambil nilai rata - rata dari masing masing spesimen. Adapun contoh perhitungan HV rata - rata spesimen awal ialah :

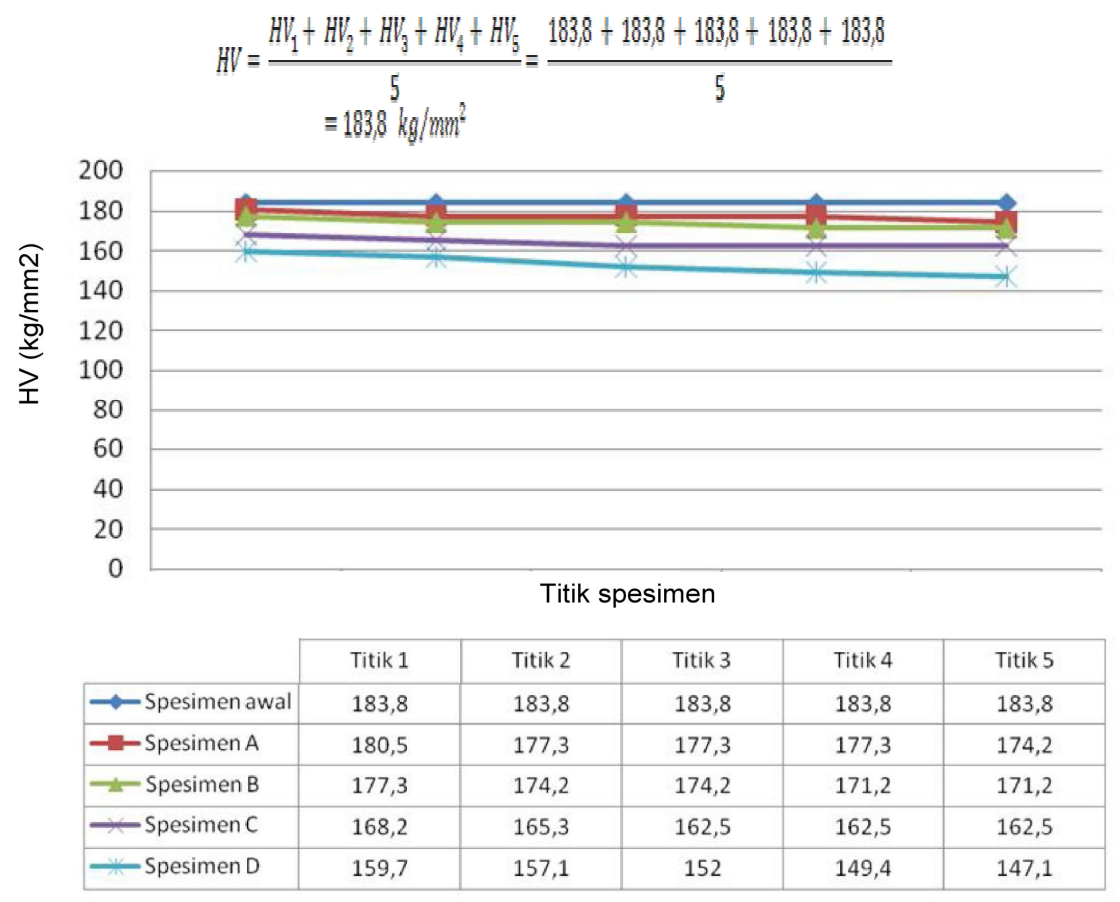

Gambar 3. Grafik Uji Kekerasan 


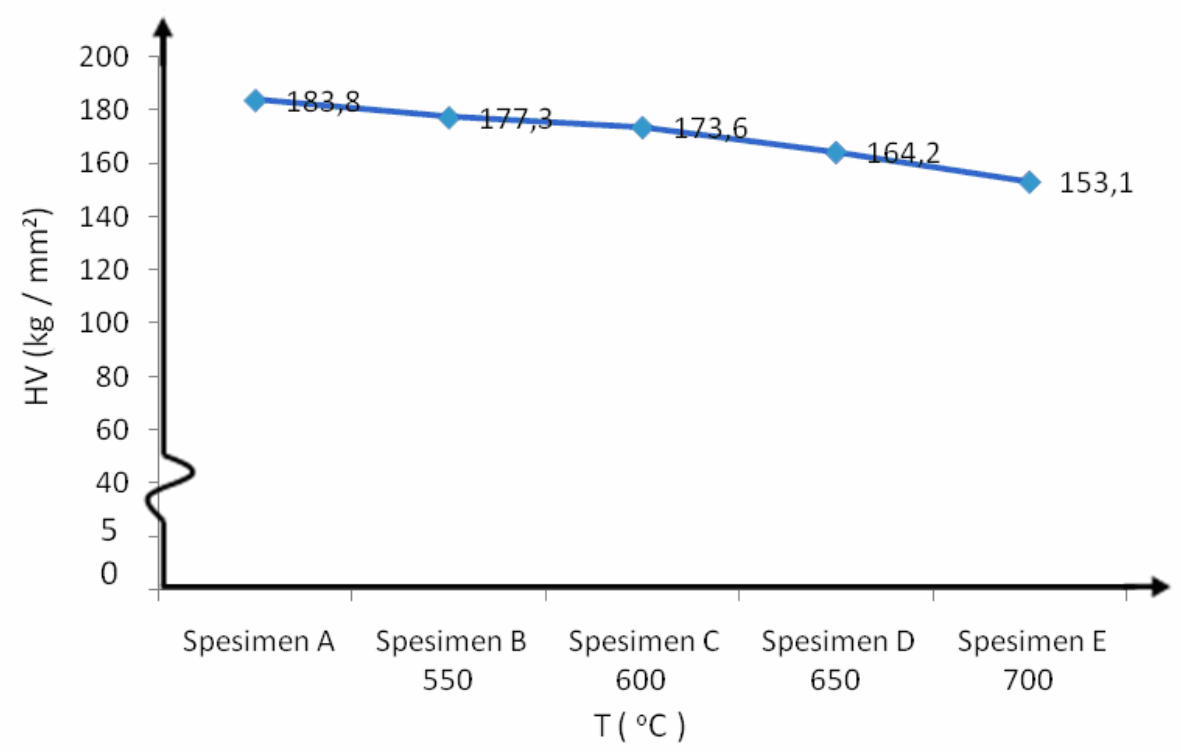

Gambar 4. Grafik Uji Kekerasan Rata-rata

\section{Hasil Uji Komposisi Kimia}

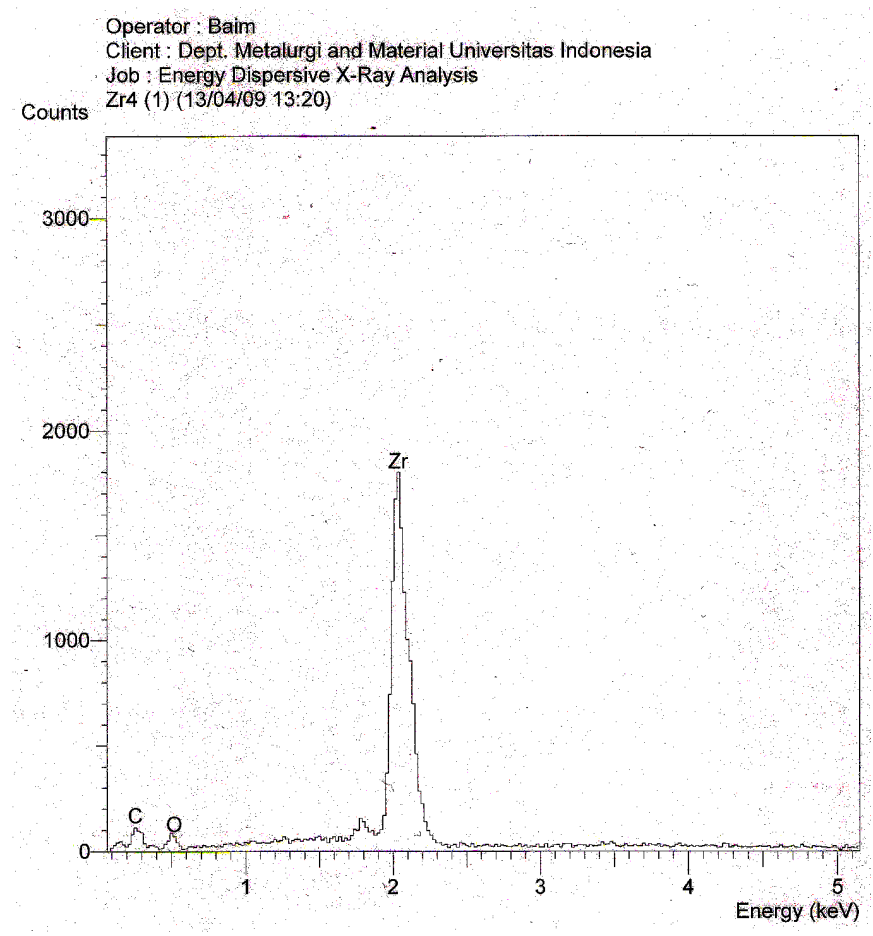

Gambar 5. Komposisi Kimia Pengukuran Titik Pertama 


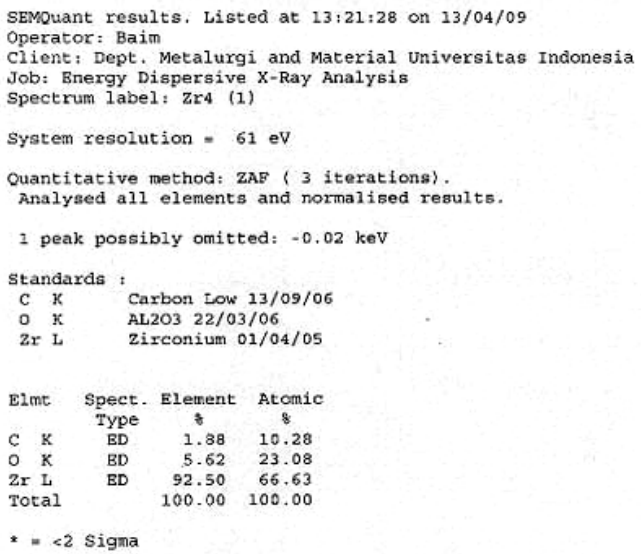

Gambar 6. Hasil Komposisi Kimia Pengukuran Titik Pertama

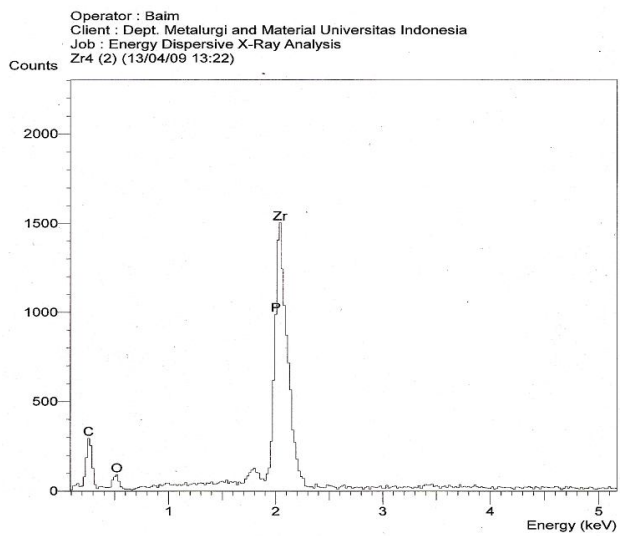

Gambar 7. Grafik Komposisi Kimia Pengukuran Titik ke Dua

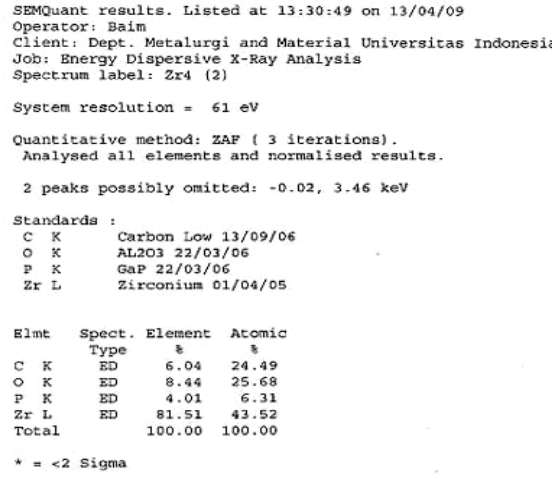

Gambar 8. Hasil Komposisi Kimia Pengukuran Titik ke 2 


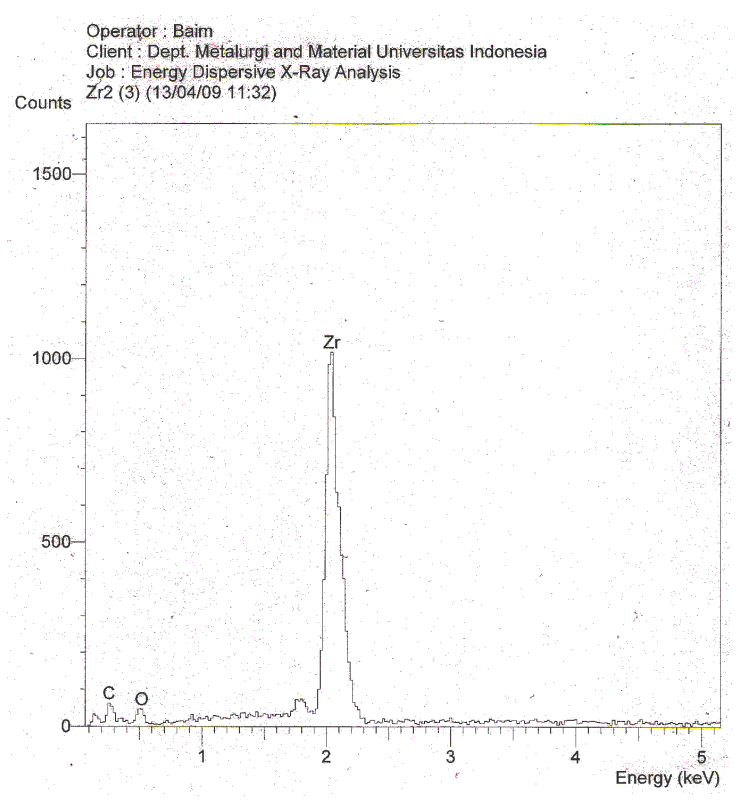

Gambar 9. Grafik Komposisi Kimia Pengukuran Titik ke Tiga

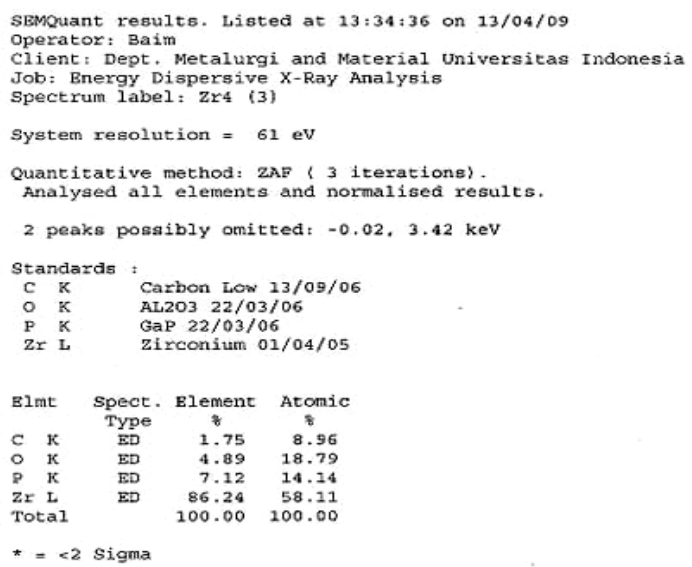

Gambar 10. Hasil Komposisi Kimia Pengukuran Titik ke Tiga

\section{Hasil Uji Struktur Mikro}

Pengamatan struktur mikro dilakukan dengan menggunakan alat mikroskop optik, kemudian hasil struktur mikro di foto dengan perbesaran 100x dan 500x setelah mengalami proses nitrocarburizing pada suhu $550^{\circ} \mathrm{C}, 600^{\circ} \mathrm{C}$, $650^{\circ} \mathrm{C}$ dan $700^{\circ} \mathrm{C}$ dengan waktu penahanan masing- masing 60 menit. Hasil 
dari pengamatan ini dapat dilihat pada gambar di bawah ini (lihat Gambar 11 sampai 20):

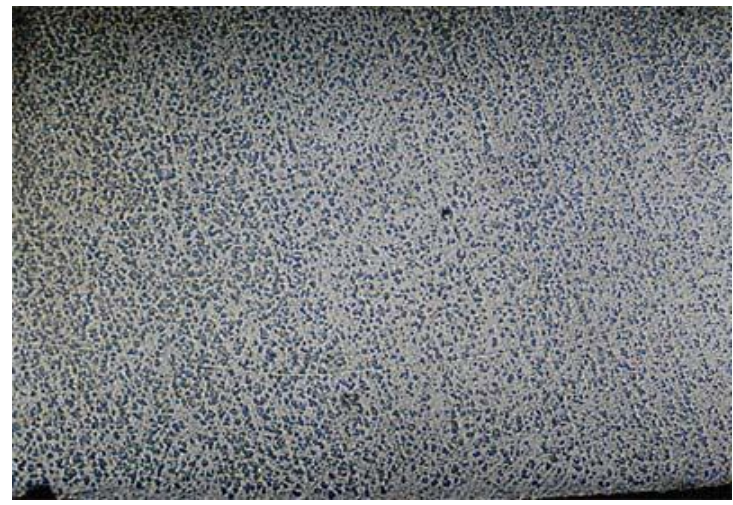

Gambar 11. Zr-4 Awal dengan Pembesaran 100×

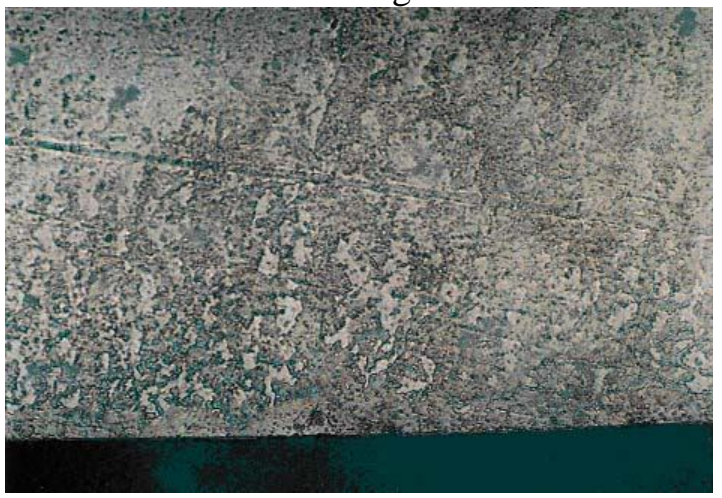

Gambar 12. Zr-4 Awal dengan Pembesaran 500×

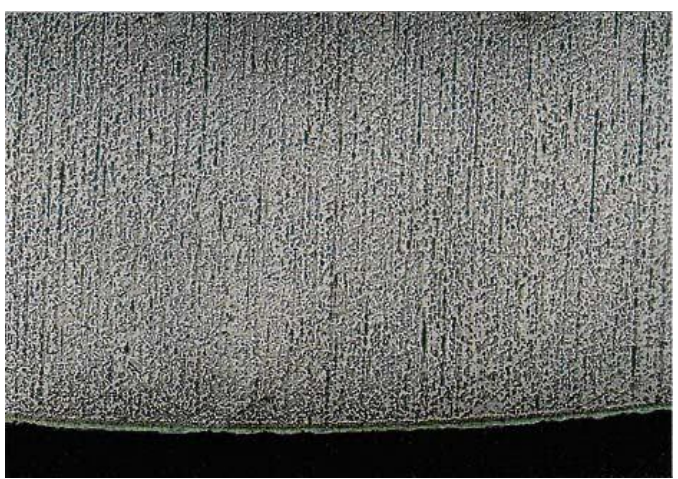

Gambar 13. Nitrocarburizing $550^{\circ} \mathrm{C}$ dengan Pembesaran $100 \times$ 


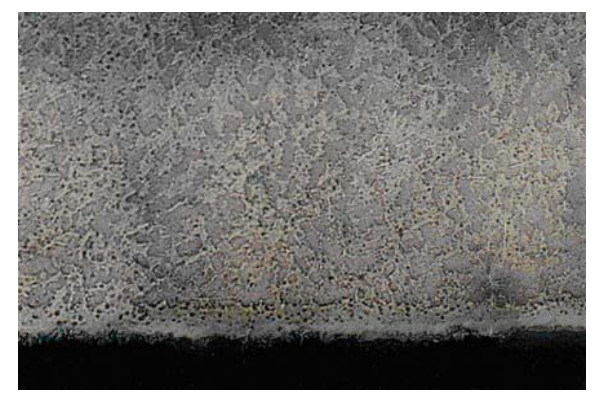

Gambar 14. Nitrocarburizing $550^{\circ} \mathrm{C}$ dengan Pembesaran $500 \times$

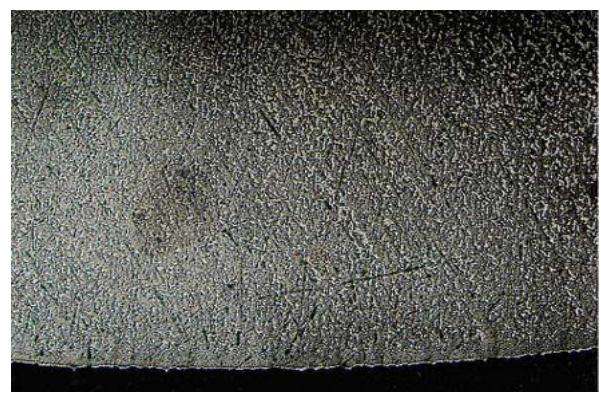

Gambar 15. Nitrocarburizing $600^{\circ} \mathrm{C}$ dengan Pembesaran $100 \times$

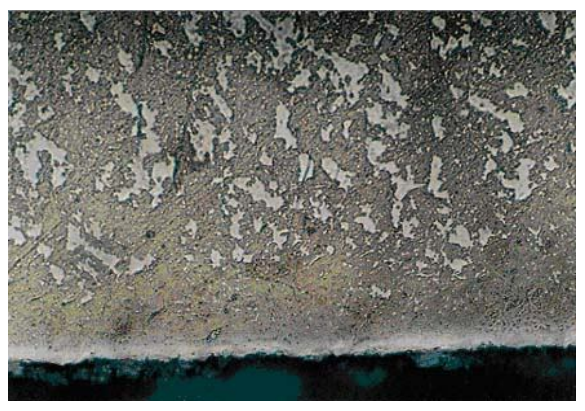

Gambar 16. Nitrocarburizing $600^{\circ} \mathrm{C}$ dengan Pembesaran $500 \times$

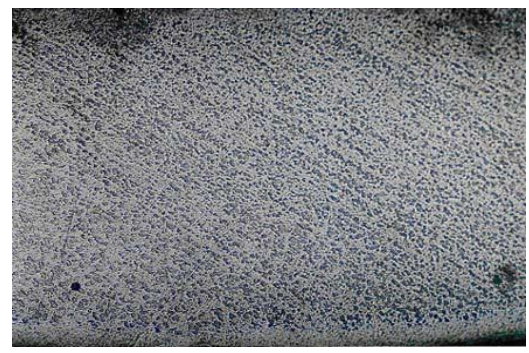

Gambar 17. Nitrocarburizing $650^{\circ} \mathrm{C}$ dengan Pembesaran $100 \times$ 


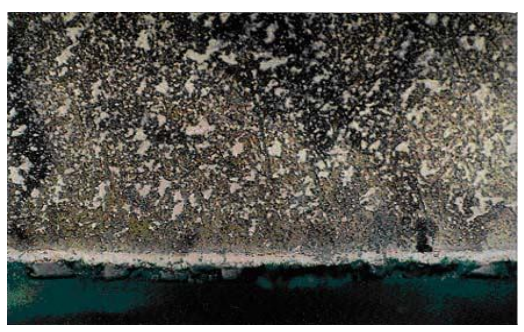

Gambar 18. Nitrocarburizing $650^{\circ} \mathrm{C}$ dengan Pembesaran $500 \times$

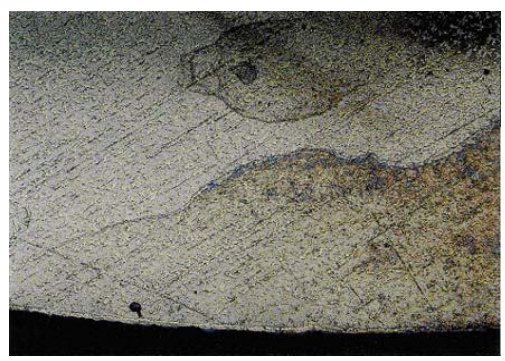

Gambar 19. Nitrocarburizing $700^{\circ} \mathrm{C}$ dengan Pembesaran $100 \times$

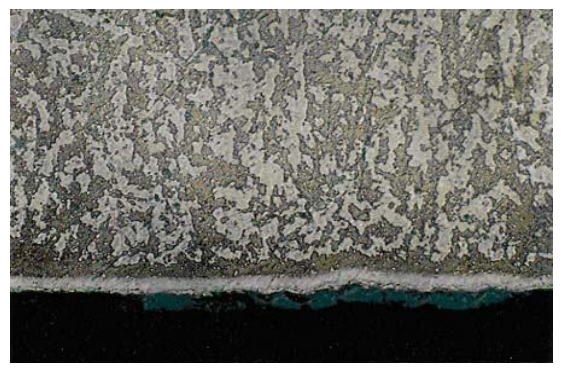

Gambar 20. Nitrocarburizing $700^{\circ} \mathrm{C}$ dengan Pembesaran $500 \times$

\section{Hasil Kedalaman Nitrogen dan Carbon Dalam Proses Nitrocarburizing}

Pada penelitian ini hanya di fokuskan pada kedalaman nitrogen dan carbon pada permukaan sampel baja setelah mengalami proses nitrocarburizing. Hasil dari kedalaman nitrogen dan carbon pada permukaan sampel baja dapat dilihat pada tabel dan gambar di bawah ini. 
Tabel 3. Data Hasil Kedalaman Nitrogen dan Carbon

Pada Suhu $550^{\circ} \mathrm{C}, 600^{\circ} \mathrm{C}, 650^{\circ} \mathrm{C}$ dan $700^{\circ} \mathrm{C}$

\begin{tabular}{|c|c|c|c|c|}
\hline $\begin{array}{l}\text { Kode } \\
\text { Sampel }\end{array}$ & $\begin{array}{c}\text { No } \\
\text { Penelitian }\end{array}$ & $\begin{array}{c}\text { Kedalaman } \\
\text { Nitrocarburizing } \\
(\mu \mathrm{m})\end{array}$ & $\begin{array}{c}\text { Rata- rata } \\
\text { Kedalaman } \\
(\mu \mathrm{m})\end{array}$ & $\begin{array}{l}\text { Waktu Tahan } \\
\quad \text { (menit) }\end{array}$ \\
\hline \multirow[t]{6}{*}{ Awal } & 1 & 0 & 0 & 60 \\
\hline & 2 & 0 & & \\
\hline & 3 & 0 & & \\
\hline & 4 & 0 & & \\
\hline & 5 & 0 & & \\
\hline & 6 & 0 & & \\
\hline \multirow[t]{6}{*}{$550^{\circ} \mathrm{C}$} & 1 & 4,2 & 4,7 & 60 \\
\hline & 2 & 4,8 & & \\
\hline & 3 & 4,3 & & \\
\hline & 4 & 5,4 & & \\
\hline & 5 & 4,6 & & \\
\hline & 6 & 5,0 & & \\
\hline \multirow[t]{6}{*}{$600^{\circ} \mathrm{C}$} & 1 & 11,4 & 11,9 & 60 \\
\hline & 2 & 12,5 & & \\
\hline & 3 & 12,1 & & \\
\hline & 4 & 11,9 & & \\
\hline & 5 & 12,0 & & \\
\hline & 6 & 11,8 & & \\
\hline \multirow[t]{6}{*}{$650^{\circ} \mathrm{C}$} & 1 & 15,7 & 16,6 & 60 \\
\hline & 2 & 16,4 & & \\
\hline & 3 & 16,8 & & \\
\hline & 4 & 18,1 & & \\
\hline & 5 & 15,3 & & \\
\hline & 6 & 17,4 & & \\
\hline \multirow[t]{6}{*}{$700^{\circ} \mathrm{C}$} & 1 & 25,6 & 26.3 & 60 \\
\hline & 2 & 24,8 & & \\
\hline & 3 & 27,2 & & \\
\hline & 4 & 26,0 & & \\
\hline & 5 & 27,8 & & \\
\hline & 6 & 26,5 & & \\
\hline
\end{tabular}

Gambar 21 adalah grafik dari kedalaman nitrogen dan carbon sampel awal, $550^{\circ} \mathrm{C}, 600^{\circ} \mathrm{C}, 650^{\circ} \mathrm{C}$ dan $700^{\circ} \mathrm{C}$ terhadap suhu proses nitrocarburizing.

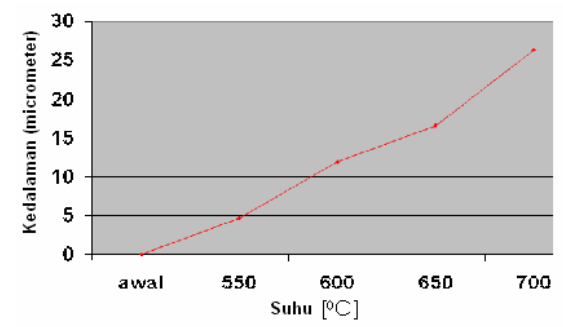

Gambar 21. Grafik Kedalam Nitrogen dan Carbon 


\section{PEMBAHASAN HASIL PENGUJIAN}

Dari hasil pengamatan dan perhitungan uji kekerasan pada Gambar 3 dan 4 dapat dilihat bahwa hasil kekerasan sampel awal adalah sebesar 177,3 $\mathrm{kg} / \mathrm{mm}^{2}$, kekerasan sampel pada suhu $550^{\circ} \mathrm{C}$ adalah sebesar $171,7 \mathrm{~kg} / \mathrm{mm}^{2}$, kekerasan sampel pada suhu $600^{\circ} \mathrm{C}$ adalah sebesar $162,52 \mathrm{~kg} / \mathrm{mm}^{2}$, kekerasan sampel pada suhu $650^{\circ} \mathrm{C}$ adalah sebesar $159,82 \mathrm{~kg} / \mathrm{mm}^{2}$, dan kekerasan sampel pada suhu $700^{\circ} \mathrm{C}$ adalah sebesar $151,52 \mathrm{~kg} / \mathrm{mm}^{2}$. Dari penjelasan di atas dapat diketahui bahwa kekerasan terendah terdapat pada sampel dengan suhu $700^{\circ} \mathrm{C}$ yang telah mengalami proses nitrocarburizing, sedangkan kekerasan tertinggi terdapat pada sampel awal yang belum mengalami proses nitrocarburizing.

Dari hasil pengamatan dan pengujian uji komposisi kimia pada sampel awal yang dilakukan pada tiga titik sembarang, kandungan komposisi kimia yang terdapat pada sampel awal terdiri dari :1).Titik pertama: carbon sebesar $31,21 \%$, oksigen sebesar $33,42 \%$, zirconium sebesar $35,37 \%$. 2). Titik kedua, carbon sebesar 18,40\%, oksigen sebesar 36,04 \%, zirconium sebesar $45,57 \%$. 3). Titik ketiga: carbon sebesar 7,94\%, oksigen sebesar 26,95\%, zirconium sebesar $65,10 \%$

Dari hasil pengujian dan pengamatan struktur mikro pada tabel 3 dan gambar 11 sampai 20 dapat diketahui kedalaman nitrocarburizing pada sampel awal, $550^{\circ} \mathrm{C}, 600^{\circ} \mathrm{C}, 650^{\circ} \mathrm{C}$ dan $700^{\circ} \mathrm{C}$ dengan waktu tahan 60 menit adalah sebagai berikut : Sampel awal tidak mempunyai kedalaman nitrocarburizing sebab belum mengalami proses nitrocarburizing. Pada sampel suhu $550^{\circ} \mathrm{C}$ waktu tahan 60 menit mempunyai kedalaman nitrocarburizing $15,0 \mu \mathrm{m}$ atau $0,015 \mathrm{~mm}$. Pada sampel suhu $600^{\circ} \mathrm{C}$ waktu tahan 60 menit mempunyai kedalaman nitrocarburizing $30,4 \mu \mathrm{m}$ atau 0,0304 mm. Pada sampel suhu $650^{\circ} \mathrm{C}$ waktu tahan 60 menit mempunyai kedalaman nitrocarburizing $36,6 \mu \mathrm{m}$ atau $0,0366 \mathrm{~mm}$. Pada sampel suhu $700^{\circ} \mathrm{C}$ waktu tahan 60 menit mempunyai kedalaman nitrocarburizing $42,1 \mu \mathrm{m}$ atau 0,0421 $\mathrm{mm}$. Jadi semakin tinggi temperatur nitrocarburizing maka semakin dalam nitrogen dan carbon yang terdifusi.

\section{KESIMPULAN}

1. Hasil pengujian yang digunakan dalam penelitian ini adalah material kelongsong nuklir pada Pembangkit Listrik Tenaga Nuklir (PLTN), dari uji komposisi kimia ternyata material tersebut mempunyai kadar unsur carbon $3,2 \%$, oksigen $6,3 \%$, phosphor 5,5\% dan zirconium $85 \%$ 
2. Dari hasil uji kekerasan dapat diketahui bahwa semakin tinggi suhu pemanasan nitrocarburizing maka nilai kekerasannya (HV) semakin kecil/semakin rendah

3. Hasil pengukuran dan pengamatan struktur mikro dapat disimpulkan bahwa semakin tinggi suhu pemanasan nitrocarburizing maka semakin dalam nitrogen dan carbon yang terdifusi pada zirconium, begitu juga sebaliknya

4. Dari hasil penelitian yang telah dilakukan di laboratorium, ternyata proses nitrocarburizing tidak dapat meningkatkan daya tahan pada material zirconium.

\section{DAFTAR PUSTAKA}

1. A. RAMCHANDANI, JK. DENNIS, 1988, "Heat Treat". Met.2,34,.

2. A.M. KLIAUGE, M.POHL, 1998, "Coat Technol”, 98, 1205.

3. G.A. COLLINS, R. HUTCHINGA, 1995, "Surf Coat Technol", 74-75, 417,

4. W. ENSINGER, 1998, "Surf Coat Technol", 100-101, 341.

5. SPALVINS, T AND KOVACS, W, 1990, Ion Nitriding Aand Ion Carburizing, ASM International, Oihio.

6. ANONIM, 1991, "The Metallographic Laboratory Its Purpose, Fungtion And Design Buehler, AB Apparatus For Microstructural Analysis Waukegan Road - Lake Bluff', Illindis USA 60044.

7. I. KAMENICHNY, 1990, "Heat Treatment", Moscow.

8. WANG LIANG, 2003, “Applied Surface Science”, 211, 308-314.

9. U. SUDJADI ET AL., 2009, "Pengerasan Permukaan (surface Hardening) Material Dengan Technologi Plasma Diskrit Aplikasi Pada KomponenFasilitas Nuklir Dan PLTN", research report I, Program Block Grant Bidang Iptek Nuklir, DIKTI-BATAN,No; 06545/KS 0001.

10. LAMBERT J, ET AL.Oxide Fuels, Vol. 10 A1994, "in Mat. Science and Tech". p.121. 